\title{
Corrigendum: The non-canonical mitochondrial inner membrane presequence translocase of trypanosomatids contains two essential rhomboid-like proteins
}

Anke Harsman, Silke Oeljeklaus, Christoph Wenger, Jonathan L. Huot, Bettina Warscheid \& André Schneider

Nature Communications 7:13707 doi: 10.1038/ncomms13707 (2016); Published 19 Dec 2016; Updated 30 Jun 2017

The original version of this Article contained an error in the gene ID for TimRhom I, cited in the Methods, which specified an unrelated gene. The correct gene ID for TimRhom I is Tb927.9.8260. This has now been corrected in both the PDF and HTML versions of the Article. reproduction in any medium or format, as long as you give appropriate credit to the original author(s) and the source, provide a link to the Creative Commons
license, and indicate if changes were made. The images or other third party material in this article are included in the article's Creative Commons license, unless indicated otherwise in a credit line to the material. If material is not included in the article's Creative Commons license and your intended use is not permitted by statutory regulation or exceeds the permitted use, you will need to obtain permission directly from the copyright holder. To view a copy of this license, visit http://creativecommons.org/licenses/by/4.0/

(C) The Author(s) 2017 